\title{
Comparing the prevalence of metabolic syndrome in systemic lupus erythematosus, rheumatoid arthritis and psoriatic arthritis: A cross sectional study
}

\author{
Maryam Mobini ${ }^{1 *}$, Fatemeh Niksolat ${ }^{2}$, Reza Ali Mohammadpour ${ }^{3}$, Sara Sadr $^{4}$, Saeed Dashti dargahloo ${ }^{4}$ \\ ${ }^{l}$ Department of Internal Medicine, Diabetes Research Center, Faculty of Medicine, Mazandaran University of Medical Sciences, \\ Sari, Iran; ${ }^{2}$ Department of Internal Medicine, Orthopedic Research Center, Faculty of Medicine, Mazandaran University of Medical \\ Sciences, Sari, Iran; ${ }^{3}$ Department of Biostatistics, Diabetes Research Center, Faculty of Health, Mazandaran University of Medical \\ Sciences, Sari, Iran; ${ }^{4}$ Faculty of Medicine, Mazandaran University of Medical Sciences, Sari, Iran
}

\begin{abstract}
Evidence suggests an association between metabolic syndrome (MetS) and its complications in rheumatologic disorders. It has a proinflammatory role and leads to increased risk of morbidity and mortality. The present study evaluated and compared the prevalence of MetS in participants with systemic lupus erythematosus (SLE), rheumatoid arthritis (RA), and psoriatic arthritis (PsA). Two hundred fifty-three patients, including 68 SLE, 140 RA, and 45 PsA patients, were recruited for this study. Their demographic data, clinical features, and laboratory parameters were compared with those of age-matched controls $(n=123)$. MetS was diagnosed based on the 2005 National Cholesterol Education Program (Adult Treatment Panel III) (NCEP/ATP III) and International Diabetes Federation (IDF) definitions. The prevalence of MetS in patients and controls was compared. Statistical analysis was performed in SPSS version 19, and results were considered significant at $p<0.05$. The mean ages of SLE, RA, and PsA patients were 42.14 $\pm 11.5,44.00 \pm 9.8$, and 44.70 \pm 5.0 years, respectively. Based on NCEP/ATP III criteria, MetS was present in $48.5 \%$ of SLE patients, $55.5 \%$ of PsA patients, $31.4 \%$ of RA patients, and $34.9 \%$ of controls $(p=0.007)$. The prevalence of MetS was high in patients with PsA and SLE, while arterial hypertension was more prevalent in PsA patients, and lower levels of blood sugar were seen in those with RA. The components of MetS should be routinely investigated in patients with these disorders to make early diagnoses and determine appropriate management plans.
\end{abstract}

Keywords: metabolic syndrome, psoriatic arthritis, rheumatoid arthritis, systemic lupus erythematosus.

\section{Introduction}

Coronary artery disease is a leading cause of morbidity and mortality in patients with systemic lupus erythematosus (SLE), rheumatoid arthritis (RA), and psoriatic arthritis (PsA). It has been reported that female SLE patients have a 5-6-fold higher risk of developing cardiovascular disorders (CVD), and the risk for women with SLE aged 35-44 years is increased more than 50 fold [1]. CVD was more prevalent in RA (10.5\%) than in PsA $(7.2 \%)$ (2). RA patients have a 2-3 fold higher risk of myocardial infarction and up to $50 \%$ higher risk of CVD mortality [2].

Metabolic syndrome (MetS) includes a group of classic CVD risk factors such as central obesity, hypertension, hypertriglyceridemia (TG), and low highdensity lipoprotein cholesterol (HDL-c) [3]. Moreover, MetS is related to the inflammatory response and pro inflammatory cytokines such as IL-6 and TNF- $\alpha$ that facilitate insulin resistance. Patients with MetS are reported to present high levels of C-related protein (CRP), interleukin-1 $\beta$ (IL-1 $\beta$ ), IL-1, P-selectin, intercellular adhesion molecule, and leptin [4,5]. Various medications such as anti-inflammatory and immunosuppressive drugs may play a role in MetS and CVD [6]. The prevalence rates of MetS in SLE, RA, and PsA patients were found in different studies to be $16.3 \%-45.2 \%, 13.9 \%-51.3 \%$, and $25.5 \%-44 \%$, respectively [7-12]. Some studies have shown that MetS and its components are more prevalent in PsA than in RA [7,13,14], but their prevalence rates are the same in SLE and RA [15].

SLE, RA, and PsA are three prevalent and indicator disorders in rheumatology. The evaluation of comorbidities may play a role in prioritizing and selecting appropriate treatments and management. The present study evaluated and compared the prevalence of MetS in these three disorders. Focus was also placed on some

\footnotetext{
* Corresponding Author: Maryam Mobini, E-mail: mmobini50@yahoo.com, Tel: +98 11 33350672, Fax: +98 1133264044 Received: 23 August 2017; Accepted: 16 October 2017
} 
characteristics of these disorders in regard to MetS and the factors that might relate to them.

\section{Materials and Methods \\ Patients}

A cross-sectional study was conducted over 10 months (January-December 2016) involving 68 consecutive SLE patients diagnosed according to the Systemic Lupus International Collaborating Clinics classification criteria (SLICC) 2012 [16], 140 RA patients diagnosed according to the American College of Rheumatology/European League Against Rheumatism criteria [17], 45 PsA patients diagnosed according to the classification criteria for psoriatic arthritis (CASPAR) [18], and 123 age-matched, eligible controls attending two referral centers over this period, including patients without inflammatory rheumatic disease (such as osteoarthritis, mechanic low back pain, and fibromyalgia). Patients with other rheumatologic disorders, including overlap syndrome, and patients using glucocorticoids for other diseases were excluded. The patients ranged in age from 20 to 60 years. Five patients with SLE, 3 patients with PsA, and 12 patients with RA were excluded from the study, because they were found to be outside the age range. Sequential sampling was performed to find a statistically significant difference between at least two groups. The minimum sample size was calculated as 45 in PsA with a higher MetS prevalence rate, a $95 \%$ confidence level, and a power of $80 \%$. In order to reduce potential bias, the researchers attempted to recruit participants from a certain age range and from both private and public services.

\section{Assessments and data collection}

Patients in each groups were evaluated clinically based on disease: Systemic Lupus Disease Activity Index (SLEDAI), Systemic Lupus Damage Index (SDI), and Health Assessment Questionnaire (HAQ) for SLE; Disease Activity Index 28 (DAS) and HAQ for RA and PSA.

All participants were clinically and biochemically assessed to define their metabolic profiles: type 2 diabetes with or without treatment, arterial blood pressure, lipid profile (HDL-c and TG), fasting blood glucose, and waist circumference.

MetS was assessed and recorded consecutively by rheumatologists according to the National Cholesterol Educational Program Adult Treatment Panel III (NCEP ATP III) and IDF $[3,19]$. MetS was considered to be present based on the NCEP criteria if patients met three or more of the following conditions:

1. Waist circumference $\geq 102 \mathrm{~cm}$ for men and $\geq 88 \mathrm{~cm}$ for women

2. Patient is currently using an antihypertensive agent, has a systolic blood pressure $\geq 130 \mathrm{mmHg}$, or a diastolic blood pressure $\geq 85 \mathrm{mmHg}$

3. Level of HDL cholesterol $<40 \mathrm{mg} / \mathrm{dl}$ for men and $<50 \mathrm{mg} / \mathrm{dl}$ for women

4. Level of TGs $\geq 150 \mathrm{mg} / \mathrm{dl}$

5. Fasting blood glucose level $\geq 110 \mathrm{mg} / \mathrm{dl}$.

The IDF criteria included a waist circumference $\geq 94$ $\mathrm{cm}$ for men and $\geq 80 \mathrm{~cm}$ for women in addition to other defining criteria of MetS. Furthermore, the variables age, gender, and treatment modalities (current therapies including HCQ, prednisolone, and methotrexate) were also considered. The cumulative dose of prednisolone was calculated based on the duration of treatment and cumulative dosage (grams) of prednisone or equivalent medication at enrollment in the study as well as the application of glucocorticoid pulse therapy.

Each patient's waist circumference was measured at the end of a normal expiration, in a horizontal line at the level of the iliac crest, parallel to the floor. Blood pressure (BP) was measured twice at rest, and the lowest measure was used for systolic and diastolic blood pressure.

Blood was drawn from patients after an overnight fasting period, and glucose and lipid profiles [total cholesterol, HDL cholesterol, low-density lipoprotein cholesterol (LDL-c), and TGs] were measured enzymatically.

\section{Statistical analysis}

Demographic and clinical features and prevalence of MetS and its components in patients and controls were evaluated. The age-adjusted prevalence rate was calculated by direct methods. Statistical analysis was performed using ANOVA to compare the quantitative variables, and chi-square tests were used to compare qualitative variables among the 4 groups using SPSS version 19 (Chicago, USA). Results were considered significant at $p<0.05$.

\section{Results}

Two hundred fifty-three patients, 68 SLE, 140 RA, and 45 PsA, and 123 age-matched controls, completed the study. The mean age of participants was $43.69 \pm 9.0$, and 280 $(74.5 \%)$ were female. The mean ages of SLE, RA, PsA patients, and controls were 42.14 $\pm 11.5,44.00 \pm 9.8$, $44.70 \pm 5.0$, and $43.30 \pm 10.5$ years, respectively ( $p=0.259$ ). Table 1 demonstrates the demographic data, clinical and laboratory characteristics in SLE, PsA, RA patients, and controls. 
Table 1. Demographic data, clinical and laboratory characteristics in SLE, PsA, RA patients and controls

\begin{tabular}{lcccccc}
\hline & SLE(68) & PsA (N=45) & RA (140) & $\begin{array}{c}\text { Controls } \\
(\mathbf{1 2 3})\end{array}$ & $\begin{array}{c}\text { P } \\
\text { value* }\end{array}$ & $\begin{array}{c}\text { Post hoc } \\
\text { test P** }\end{array}$ \\
\hline Age & $42.14 \pm 11.52$ & $44.00 \pm 9.8$ & $44.70 \pm 5.0$ & $43.30 \pm 10.5$ & 0.259 & - \\
Female: N(\%) & $66(97.1 \%)$ & $29(66.4 \%)$ & $115(82.1 \%)$ & $70(56.9 \%)$ & $<0.001$ & \\
History of hypothyroidism: N(\%) & $22(32.4 \%)$ & $19(42.2 \%)$ & $13(9.3 \%)$ & - & $<0.001$ & - \\
Family history of MI or CVA: & $18(27.3 \%)$ & $20(44.4 \%)$ & $37(26.4 \%)$ & - & 0.062 & - \\
$\quad$ N(\%) & $29.27 \pm 5.05$ & $29.67 \pm 5.7$ & $30.17 \pm 6.9$ & $28.69 \pm 5.0$ & 0.241 & - \\
BMI & $96.75 \pm 11.0$ & $99.47 \pm 13.5$ & $99.43 \pm 17.8$ & $97.06 \pm 11.7$ & 0.420 & PsA vs others: \\
Waist circumference & $119.34 \pm 15.3$ & $130.56 \pm 14.75$ & $122.61 \pm 12.9$ & $122.32 \pm 14.1$ & 0.001 & $<0.005$ \\
Sys BP & & & & & & PsA vs others: \\
& $71.76 \pm 9.1$ & $80.53 \pm 13.3$ & $74.96 \pm 10.1$ & $74.93 \pm 8.5$ & 0.001 & $<0.005$ \\
Dias BP & $175.26 \pm 37.4$ & $183.40 \pm 28.0$ & $191.33 \pm 75.8$ & $196.24 \pm 41.7$ & 0.076 & - \\
Cholesterol & $100.10 \pm 31.3$ & $114.00 \pm 22.6$ & $107.80 \pm 28.4$ & $116.29 \pm 30.5$ & 0.003 & SLE vs controls: \\
LDL & $49.12 \pm 13.8$ & $47.93 \pm 9.6$ & $51.89 \pm 15.0$ & $48.46 \pm 12.3$ & 0.138 & 0.002 \\
HDL & $135.57 \pm 64.7$ & $131.60 \pm 51.4$ & $136.49 \pm 61.0$ & $147.84 \pm 80.7$ & 0.401 & - \\
TG & $93.72 \pm 18.9$ & $96.80 \pm 13.2$ & $90.79 \pm 16.5$ & $101.54 \pm 26.4$ & $<0.001$ & RA vs controls: \\
FBS & & & $<0.001$ \\
\hline SLE & & &
\end{tabular}

SLE: systemic lupus erythematosus, PsA: psoriatic arthritis, RA: rheumatoid arthritis.

* Derived from one-way analysis of variance (continuous variables) or Chi-Square test (categorical variables).

** Post hoc multiple comparison of continuous variables was performed by Tukey's test.

At the time of the study, $63(92.6 \%)$ patients in the SLE group were receiving prednisolone, 12 (17.6\%) methotrexate, and $49(72.1 \%)$ used hydroxychloroquine. The medications in RA group were as follows: prednisolone in $105(75 \%)$, methotrexate in $82(58.6 \%)$, hydroxychloroquine in $78(55.7 \%)$, leflunomide in 8 $(5.7 \%)$, and sulfasalazine in $14(10 \%)$. Nineteen patients (42.2\%) with PsA were receiving prednisolone, 8 patients
$(17.8 \%)$ were receiving sulfasalazine, 28 patients $(62.2 \%)$ were receiving methotrexate, and $3(6.6 \%)$ were using biologic agents (Etanercept or infliximab). PsA patients had higher scores of HAQ and DAS 28, which implies a greater degree of disability and disease activity $(p<0.05)$. Table 2 shows the clinical and laboratory characteristics of SLE, PsA, and RA patients.

Table 2. Clinical and laboratory characteristics in SLE, PsA, and RA patients

\begin{tabular}{|c|c|c|c|c|c|}
\hline & SLE(68) & $\begin{array}{c}\text { PsA } \\
(\mathrm{N}=45)\end{array}$ & $\mathbf{R A}(\mathbf{1 4 0})$ & $\begin{array}{c}\mathbf{P} \\
\text { value* }\end{array}$ & $\begin{array}{l}\text { Post hoc test } \\
\text { P** }\end{array}$ \\
\hline Disease duration & $6.43 \pm 6.5$ & $2.00 \pm 5.1$ & $3.88 \pm 4.0$ & $<0.001$ & $\begin{array}{l}\text { SLE vs others: } \\
<0.05\end{array}$ \\
\hline HAQ score, mean \pm SD & $0.268 \pm 0.4$ & $1.14 \pm 1.5$ & $0.545 \pm 0.6$ & $<0.001$ & $\begin{array}{l}\text { PsA vs others: } \\
\quad<0.001\end{array}$ \\
\hline DAS 28 score, mean \pm SD & - & $3.70 \pm 1.45$ & $3.11 \pm 1.3$ & 0.023 & - \\
\hline SLEDAI, mean \pm SD & $1.12 \pm 2.0$ & - & - & - & - \\
\hline $\mathrm{SDI}$, mean $\pm \mathrm{SD}$ & $0.75 \pm 1.2$ & - & - & - & - \\
\hline Prednisolone use: $\mathrm{N}(\%)$ & $63(95.5 \%)$ & $19(42.2 \%)$ & $105(91.3 \%)$ & $<0.001$ & $\begin{array}{l}\text { SLE vs others: } \\
\quad<0.005\end{array}$ \\
\hline Prednisone, current daily dose, mean \pm SD $(\mathrm{mg} / \mathrm{d})$ & $11.89 \pm 11.0$ & $6.57 \pm 12.2$ & $6.08 \pm 3.6$ & 0.001 & $\begin{array}{l}\text { SLE vs others: } \\
\quad<0.005\end{array}$ \\
\hline Hydroxychloroquine use: $\mathrm{N}(\%)$ & $49(74.2 \%)$ & - & $78(56.1 \%)$ & 0.009 & - \\
\hline $\begin{array}{l}\text { Hydroxychloroquine, current daily dose, mean } \pm \text { SD } \\
(\mathrm{mg} / \mathrm{d})\end{array}$ & $271.42 \pm 106.0$ & - & $136.12 \pm 11.5$ & $<0.001$ & - \\
\hline Methotraxate use: N(\%) & $12(17.6 \%)$ & $28(62.2 \%)$ & $82(59 \%)$ & $<0.001$ & \\
\hline
\end{tabular}

SLE: systemic lupus erythematosus, PsA: psoriatic arthritis, RA: rheumatoid arthritis.

* Derived from one-way analysis of variance (continuous variables) or Chi-Square test (categorical variables).

** Post hoc multiple comparison of continuous variables was performed by Tukey's test. 
Based on NCEP/ATP III, MetS was present in 48.5\% of SLE patients, $55.5 \%$ of PsA patients, $31.4 \%$ in RA patients, and $34.9 \%$ in controls $(p=0.007)$. Its prevalence among these patients, based on IDF criteria, was 50\%, $57.8 \%, 35 \%$, and $38 \%$ in SLE, PsA, RA patients, and controls, respectively. The comparison of MetS components showed a higher waist circumference in SLE $(p=0.001)$ patients and hypertension in PsA patients $(p=0.000)$. The prevalence of hypothyroidism was higher in PsA patients. Table 3 demonstrates MetS and its components in SLE, PsA, RA patients, and controls.

Table 3. Metabolic syndrome and its components in SLE, PsA, RA patients, and controls

\begin{tabular}{|c|c|c|c|c|c|}
\hline & SLE(68) & PsA $(\mathrm{N}=45)$ & $\mathbf{R A}(140)$ & $\begin{array}{c}\text { Controls } \\
\text { (123) }\end{array}$ & P value* \\
\hline $\begin{array}{l}\text { Metabolic syndrome NCEP): N(\%) } \\
\text { (crude prevalence) }\end{array}$ & $33(48.5 \%)$ & $25(55.5 \%)$ & $44(31.4 \%)$ & $43(34.9 \%)$ & 0.007 \\
\hline (age adjusted prevalence) & $(45.8 \%)$ & $(52.1 \%)$ & $(33.8 \%)$ & $(35.1 \%)$ & \\
\hline $\begin{array}{l}\text { Metabolic syndrome (IDF): N(\%) } \\
\quad \text { (age adjusted prevalence) }\end{array}$ & $\begin{array}{l}34(50 \%) \\
(48 \%)\end{array}$ & $\begin{array}{l}26(57.8 \%) \\
(59.5 \%)\end{array}$ & $\begin{array}{l}49(35 \%) \\
(37.7 \%)\end{array}$ & $\begin{array}{l}47(38 \%) \\
(36.7 \%)\end{array}$ & 0.019 \\
\hline $\begin{array}{l}\text { High waist circumference according to } \\
\text { NCEP: } \mathrm{N}(\%)\end{array}$ & $54(79.4 \%)$ & $32(71.1 \%)$ & $96(69.6 \%)$ & $65(52.8 \%)$ & 0.001 \\
\hline Low HDL or treatment: $\mathrm{N}(\%)$ & $35(54.7 \%)$ & $16(35.6 \%)$ & $64(45.7 \%)$ & $54(47 \%)$ & 0.267 \\
\hline $\mathrm{TG}>150 \mathrm{mg} / \mathrm{dl}$ or treatment: $\mathrm{N}(\%)$ & $32(47.1 \%)$ & $17(37.8 \%)$ & $60(42.9 \%)$ & $46(37.4 \%)$ & 0.557 \\
\hline Glucose $\geq 100 \mathrm{mg} /$ dlor treatment: $\mathrm{N}(\%)$ & $14(13.2 \%)$ & $17(37.8 \%)$ & $36(34 \%)$ & $39(36.8 \%)$ & 0.160 \\
\hline Hypertension or treatment: $\mathrm{N}(\%)$ & $31(45.6 \%)$ & $28(62.2 \%)$ & $59(42.1 \%)$ & $32(26 \%)$ & $<0.001$ \\
\hline
\end{tabular}

SLE: systemic lupus erythematosus, PsA : psoriatic arthritis, RA: rheumatoid arthritis.

*Derived from Chi-Square Tests (categorical variables).

\section{Discussion}

This is a cross-sectional study of the prevalence of MetS in patients with SLE, PsA, and RA compared with controls. In the current study, MetS occurred more frequently in patients with PsA and SLE than in those with RA and the controls. PsA patients showed the highest prevalence of hypertension.

The population prevalence of MetS, based on NCEP/ATP III criteria, was $29 \%$ in an Iranian population (35\% in females vs. $24 \%$ in males) in the period 2005 2016 [20]. In the present study, the prevalence of MetS in the controls was $34.9 \%$, which was slightly higher than expected. The majority of patients in all groups were female, especially the SLE patients, and based on the epidemiology of these diseases, it was expected.

The causes of the variance in the prevalence of MetS in patients with rheumatic diseases are not totally clear. Contrary to Gomes et al. [10], who reported a significant increase in the prevalence of MetS in 338 patients with RA compared to 84 controls, an increased prevalence of MetS could not be demonstrated in the 140 RA patients of the current study. This is consistent with the results of Karvounaris et al. [21], who found a similar prevalence of MetS in 200 RA patients and 400 control subjects, and the findings of Mok et al. [7] with 699 RA patients and 1398 controls. The current results in comparing the rate of MetS in PsA and RA patients were consistent with those of Labitigan et al. [13] and Mok et al. [7] but inconsistent with the results of Zonana-Nacach et al. [15] in SLE and RA patients. To the best of the authors' knowledge, no study has compared the prevalence rates of MetS in these three diseases.

The relationship between the prevalence of MetS and inflammatory rheumatoid diseases seems to be complex and to depend on several factors. Inflammatory cytokines such as TNF $\alpha$ and interleukin 6 (Il-6) were found to reduce insulin activity, inhibit insulin receptor auto phosphorylation, and signal transduction that leads to hyperglycemia, compensatory hyperinsulinemia, and dyslipidemia [22,23]. On the other hand, abdominal fat may be a source of the production of cytokines such as TNF $\alpha$, IL-6, and adiponectin [24]. Chronic treatment with various medications such as glucocorticoids and hydroxychloroquine, physical activity, and concomitant disorders such as hypothyroidism may contribute to changes in the incidence of hypertension, blood glucose, lipid profile, and visceral obesity. In the present study, SLE patients used more steroids and hydroxychloroquine (at higher doses), while methotrexate was more common in PsA patients (Table 2). The lower LDL values in SLE patients may be due to the greater use of statins and hydroxychloroquine for this condition. Lower levels of blood sugar in RA patients could be associated with hydroxychloroquine intake. Although the use of steroids was less common in psoriasis, the odds of MetS were higher. HAQ and DAS 28 were higher in PsA patients, which may indicate a greater incapacity in these patients 
and, as a result, a decrease in their daily physical activity. Hypothyroidism was more prevalent in PsA patients $(42.2 \%)$ and lower in those with RA $(9.3 \% ; p=0.000)$.

According to previous studies, MetS is more prevalent in patients with PsA than in those with RA, while it is seen in the same pattern in SLE and RA patients (Table 4) [7,14,15].

In the current study, MetS occurred in one-third to one-half of the patients. This is in accordance with some other studies, although a direct comparison is difficult because of differences in patient selection and some parameters such as age, disease duration and manifestations, and different modalities of immunosuppressive therapies. Considering the high prevalence of MetS in the patients of this study, routine screening for MetS components is recommended, especially in PsA and SLE patients.

Table 4. Studies on the prevalence of metabolic syndrome in patients with rheumatologic disorders

\begin{tabular}{|c|c|c|c|c|c|c|}
\hline Author & Patients & $\begin{array}{l}\text { The mean of } \\
\text { age (year) }\end{array}$ & MetS in patients & $P$ value & $\begin{array}{l}\text { Diagnostic } \\
\text { criteria }\end{array}$ & Clinical points \\
\hline $\begin{array}{l}\text { Medeiros et } \\
\text { al. [8] }\end{array}$ & $\begin{array}{c}\text { 146SLE } \\
101 \text { Controls }\end{array}$ & $41.7 \pm 12.5$ & $\begin{array}{l}\text { 45.2\% SLE } \\
32.7 \% \text { Controls }\end{array}$ & 0.04 & NCEP & $\begin{array}{l}\text { Association of MetS with } \\
\text { age, SLE duration and } \\
\text { damage index }\end{array}$ \\
\hline $\begin{array}{l}\text { Mok et al. } \\
{[25]}\end{array}$ & $\begin{array}{c}123 \text { SLE } \\
492 \text { controls }\end{array}$ & $47.9 \pm 11$ & $\begin{array}{l}16.3 \% \text { SLE } 9.6 \% \\
\text { controls }\end{array}$ & 0.03 & NCEP & $\begin{array}{l}\text { Association of MetS with } \\
\text { coronary atherosclerosis }\end{array}$ \\
\hline $\begin{array}{l}\text { Slimani et } \\
\text { al. [9] }\end{array}$ & $249 \mathrm{RA}$ & $50.1 \pm 14.5$ & $13.9 \%$ & - & NCEP & $\begin{array}{l}\text { Higher levels of ESR in } \\
\text { patients with MetS }\end{array}$ \\
\hline $\begin{array}{l}\text { Gomes et } \\
\text { al. [10] }\end{array}$ & $\begin{array}{c}338 \mathrm{RA} \\
84 \text { controls }\end{array}$ & - & $\begin{array}{c}51.3 \% \text { RA } \\
21.8 \% \text { controls }\end{array}$ & 0.001 & NCEP & \\
\hline $\begin{array}{l}\text { Haroon et } \\
\text { al. [12] }\end{array}$ & $\begin{array}{c}283 \text { PsA } \\
100 \text { controls }\end{array}$ & $\begin{array}{l}54.6 \pm 12 \\
53.7 \pm 14\end{array}$ & $44 \%$ PsA & - & $\begin{array}{l}\text { National } \\
\text { Heart, Lung, } \\
\text { and Blood } \\
\text { Institute }\end{array}$ & $\begin{array}{c}\text { significant association of } \\
\text { MetS was noted with more } \\
\text { severe PsA }\end{array}$ \\
\hline $\begin{array}{l}\text { Bostoen et } \\
\text { al. [11] }\end{array}$ & $\begin{array}{l}55 \text { PsA } \\
49 \text { Pso }\end{array}$ & & $\begin{array}{l}25.5 \% \text { PsA } \\
44.9 \% \text { Pso }\end{array}$ & 0.037 & IDF & \\
\hline $\begin{array}{l}\text { Zonana- } \\
\text { Nacach et } \\
\text { al. [15] }\end{array}$ & $\begin{array}{l}107 \mathrm{RA} \\
85 \mathrm{SLE}\end{array}$ & $\begin{array}{c}43 \pm 13 \\
\text { (overall) }\end{array}$ & $17 \%$ in both group & - & NCEP & $\begin{array}{l}\text { MetS was associated with a } \\
\text { shorter treatment period } \\
\text { with methotrexate and } \\
\text { higher HAQ score. }\end{array}$ \\
\hline $\begin{array}{l}\text { Labitigan et } \\
\text { al. [13] }\end{array}$ & $\begin{array}{l}294 \mathrm{Ps} A \\
1662 \mathrm{RA}\end{array}$ & $\begin{array}{l}55.7 \pm 11.9 \\
61.6 \pm 12.2\end{array}$ & $\begin{array}{l}27 \% \text { PsA } \\
19 \% \text { RA }\end{array}$ & 0.02 & $\begin{array}{l}\text { NCEP, IDF, } \\
\text { WHO }\end{array}$ & $\begin{array}{l}\text { PsAwas associated with } \\
\text { higher rates of obesity, DM } \\
\text { and hypertriglyceridemia. }\end{array}$ \\
\hline $\begin{array}{l}\text { Mok et al. } \\
\text { [7] }\end{array}$ & $\begin{array}{l}109 \text { PsA } \\
699 \mathrm{RA}\end{array}$ & $\begin{array}{c}50.4 \pm 10.6 \\
53.3 \pm 12\end{array}$ & $\begin{array}{l}38 \% \text { PsA } \\
20 \% \text { RA }\end{array}$ & 0.001 & $\begin{array}{l}\text { updated joint } \\
\text { consensus } \\
\text { criteria }\end{array}$ & \\
\hline $\begin{array}{l}\text { Ozkan et al. } \\
{[14]}\end{array}$ & $\begin{array}{l}102 \mathrm{PsA} \\
102 \mathrm{RA}\end{array}$ & $\begin{array}{l}44.7 \pm 11.6 \\
47.0 \pm 11.6\end{array}$ & $\begin{array}{l}40.6 \% \text { PsA } \\
24.7 \% \text { RA }\end{array}$ & 0.019 & NCEP, IDF & $\begin{array}{l}\text { A significantly increased } \\
\text { prevalence of } \\
\text { hypertriglyceridemia was } \\
\text { determined in patients with } \\
\text { PsA }\end{array}$ \\
\hline $\begin{array}{l}\text { Present } \\
\text { study } \\
\text { (according } \\
\text { NCEP) }\end{array}$ & $\begin{array}{c}68 \text { SLE } \\
140 \text { RA } \\
45 \text { PsA } \\
123 \text { controls }\end{array}$ & $\begin{array}{c}42.14 \pm 11.52 \\
44.70 \pm 5.0 \\
44.00 \pm 9.8 \\
43.30 \pm 10.5\end{array}$ & $\begin{array}{l}\text { 48.5\% SLE } \\
31.4 \% \text { RA } \\
55.5 \% \text { PsA } \\
34.9 \% \text { controls }\end{array}$ & 0.007 & NCEP, IDF & \\
\hline
\end{tabular}

MetS= metabolic syndrome, NCEP= National Cholesterol Education Program, DF=International Diabetes Federation. 
While all attempts were made to approach this study carefully and present results that are accurately interpreted, like many studies, this one had some limitations. First, the association between cardiovascular disease and MetS was not assessed, which would have helped to better analyze the real importance of detecting MetS as a promoter of future vascular damage in patients with rheumatologic disorder; however, this and similar studies allow us to recognize the role of chronic inflammation and its contribution to MetS and different diseases. Second, the sample size was relatively small due to difficulties associated with age- and gender-matching in SLE (young females), RA (middle-aged women), and
PsA (middle-aged males/females) patients.

\section{Conflicts of interest}

The authors declare no conflict of interest.

\section{Acknowledgments}

This research is a part of three investigations on metabolic syndrome in various rheumatologic diseases. These studies were supported by the Vice Chancellor of Research and Technology, Mazandaran University of Medical Sciences, Sari, Iran.

\section{References}

1. Manzi S, Meilahn EN, Rairie JE, Conte CG, Medsger TA, Jr, Jansen-McWilliams L, et al. Agespecific incidence rates of myocardial infarction and angina in women with systemic lupus erythematosus: comparison with the Framingham Study. Am J Epidemiol 1997; 145(5): 408-15, doi:10.1093/oxfordjournals.aje.a0 09122 .

2. Castaneda S, Martin-Martinez MA, Gonzalez-Juanatey C, Llorca J, Garcia-Yebenes MJ, PerezVicente $\mathrm{S}$, et al. Cardiovascular morbidity and associated risk factors in Spanish patients with chronic inflammatory rheumatic diseases attending rheumatology clinics: Baseline data of the CARMA Project. Semin Arthritis Rheum 2015; 44(6): 618-26. doi 10.1016/j.semarthrit.2014.12.002.

3. Targher G, Bertolini L, Tessari R, Zenari L, Arcaro G. The International Diabetes Federation definition of the metabolic syndrome independently predicts future cardiovascular events in Type 2 diabetic patients. The Valpolicella Heart Diabetes Study. Diabet Med 2006; 23(11) 1270-1. doi: 10.1111/j.14645491.2006.01940.x

4. Salmenniemi U, Ruotsalainen E, Pihlajamaki J, Vauhkonen I, Kainulainen S, Punnonen K, et al. Multiple abnormalities in glucose and energy metabolism and coordinated changes in levels of adiponectin, cytokines, and adhesion molecules in subjects with metabolic syndrome. Circulation 2004; 110(25): 3842 -
8. doi: 10.1161/01.CIR 0000150391.38660.9B.

5. Sidiropoulos PI, Karvounaris SA, Boumpas DT. Metabolic syndrome in rheumatic diseases: epidemiology, pathophysiology, and clinical implications. Arthritis Res Ther 2008; 10(3): 207. doi: 10.1186/ar2397.

6. Bellomio V, Spindler A, Lucero E, Berman A, Sueldo R, Berman $\mathrm{H}$, et al. Metabolic syndrome in Argentinean patients with systemic lupus erythematosus. Lupus 2009; 18(11): 1019-25. doi: 10.1177/0961203309105876.

7. Mok CC, Ko GT, Ho LY, Yu KL, Chan PT, To CH. Prevalence of atherosclerotic risk factors and the metabolic syndrome in patients with chronic inflammatory arthritis. Arthritis Care Res 2011; 63(2): 195-202. doi: 10.1002/acr.20363.

8. Medeiros MM, Xavier de Oliveira IM, Ribeiro AT. Prevalence of metabolic syndrome in a cohort of systemic lupus erythematosus patients from Northeastern Brazil: association with disease activity, nephritis, smoking, and age. Rheumatol Int 2016; 36(1): 117 24. doi: 10.1007/s00296-0153316-z.

9. Slimani S, Abbas A, Ben Ammar A, Rahal F, Khider I, Khelif K, et al. Prevalence of metabolic syndrome in Algerian rheumatoid arthritis patients. Correlation with disease activity and functional status. Diabetes Metab Syndr 2017. doi: 10.1016/j.dsx.2017.03. 029.

10. Gomes KWP, Luz AJP, Felipe
MRB, Beltrao LA, Sampaio AXC, Rodrigues CEM. Prevalence of metabolic syndrome in rheumatoid arthritis patients from Northeastern Brazil: Association with disease activity. Mod Rheumatol 2017: 1-6. doi: 10.1080/14397595.2017.1316813

11. Bostoen J, Van Praet L, Brochez L, Mielants H, Lambert J. A cross-sectional study on the prevalence of metabolic syndrome in psoriasis compared to psoriatic arthritis. J Eur Acad Dermatol Venereol 2012; 28(4): 507-11, doi: 10.1111/jdv.12071.

12. Haroon $M$, Rafiq Chaudhry $A B$, Fitzgerald O. Higher Prevalence of Metabolic Syndrome in Patients with Psoriatic Arthritis: A Comparison with a Control Group of Noninflammatory Rheumatologic Conditions. Jour Rheumatol 2016; 43(2): 463-4. doi: 10.3899/jrheum.150757.

13. Labitigan M, Bahce-Altuntas A, Kremer JM, Reed G, Greenberg JD, Jordan N, et al. Higher rates and clustering of abnormal lipids, obesity, and diabetes mellitus in psoriatic arthritis compared with rheumatoid arthritis. Arthritis careres 2014; 66(4): 600-7. doi: 10.1002/acr.22185.

14. Ozkan SG, Yazisiz H, Behlul A, Gokbelen YA, Borlu F, Yazisiz V. Prevalence of metabolic syndrome and degree of cardiovascular disease risk in patients with Psoriatic Arthritis. Eur J rheumatol 2017; 4(1): 405. doi: 10.5152/eurjrheum.2017. 16052.

15. Zonana-Nacach A, Santana- 
Sahagun E, Jimenez-Balderas FJ, Camargo-Coronel A. Prevalence and factors associated with metabolic syndrome in patients with rheumatoid arthritis and systemic lupus erythematosus. $\boldsymbol{J}$ Clin Rheumatol 2008; 14(2): 74 7. doi: 10.1097/RHU.0b013e318 16b2faa.

16. Petri M, Orbai AM, Alarcon GS, Gordon C, Merrill JT, Fortin PR, et al. Derivation and validation of the Systemic Lupus International Collaborating Clinics classification criteria for systemic lupus erythematosus. Arthritis Rheum 2012; 64(8): 2677-86. doi: 10.1002/art.34473.

17. Aletaha D, Neogi T, Silman AJ, Funovits J, Felson DT, Bingham CO, 3rd, et al. 2010 Rheumatoid arthritis classification criteria: an American College of Rheumatology/European League Against Rheumatism collaborative initiative. Arthritis Rheum 2010; 62(9): 2569-81. doi: 10.1002/art.27584.

18. Taylor W, Gladman D, Helliwell $\mathrm{P}$, Marchesoni A, Mease $\mathrm{P}$, Mielants H. Classification criteria for psoriatic arthritis: development of new criteria from a large international study. Arthritis Rheum 2006; 54(8): 2665-73. doi:10.1002/art.21972.

19. Executive Summary of The Third Report of The National Cholesterol Education Program (NCEP) Expert Panel on Detection, Evaluation, And Treatment of High Blood Cholesterol In Adults (Adult Treatment Panel III). Jama 2001; 285(19): 2486-97. doi:10.1001/ jama.285.19.2486.

20. Dalvand S, Niksima SH, Meshkani R, Ghanei Gheshlagh R, Sadegh-Nejadi S, Kooti W, et al. Prevalence of Metabolic Syndrome among Iranian Population: A Systematic Review and Meta-analysis. Iran J Public Health 2017; 46(4): 456-67.

21. Karvounaris SA, Sidiropoulos PI, Papadakis JA, Spanakis EK, Bertsias GK, Kritikos HD, et al. Metabolic syndrome is common among middle-to-older aged Mediterranean patients with rheumatoid arthritis and correlates with disease activity: a retrospective, cross-sectional, controlled, study. Ann Rheum
Dis 2007; 66(1): 28-33. doi: 10. 1136/ard.2006.053488.

22. Gupta D, Varma S, Khandelwal RL. Long-term effects of tumor necrosis factor-alpha treatment on insulin signaling pathway in HepG2 cells and HepG2 cells overexpressing constitutively active Akt/PKB. J Cell Biochem 2007; 100(3): 593-607. doi:10. 1002/jcb.21080.

23. Senn JJ, Klover PJ, Nowak IA, Mooney RA. Interleukin-6 induces cellular insulin resistance in hepatocytes. Diabetes 2002; 51(12): 3391-9, doi: 10.2337/ diabetes.51.12.3391

24. Matsuzawa Y. The metabolic syndrome and adipocytokines. Expert Rev Clin Immunol 2007; 3(1): 39-46. doi: 10.1586/ 1744666X.3.1.39.

25. Mok CC, Poon WL, Lai JP, Wong CK, Chiu SM, Wong CK, et al. Metabolic syndrome, endothelial injury, and subclinical atherosclerosis in patients with systemic lupus erythematosus. Scand J Rheumatol 2010; 39(1): 42-9, doi: 10.3109/ 03009740903046668 . 